\title{
Developing Skill of Art Using the Explicit Instruction Model with Finger Painting Media in Kindergarten
}

\author{
Mohammad Dani Wahyudi, Amanah Fathani \\ Department of Early Childhood Teacher Education \\ Faculty of Teacher Training and Education \\ Universitas Lambung Mangkurat \\ Banjarmasin, Indonesia \\ mdaniwahyudi@ulm.ac.id
}

\begin{abstract}
The purpose of this research is to develop children of the art in drawing objects around them on Kindergarten. This research applied qualitative approach with classroom action research type. Analyzed using descriptive qualitative technique. The data was collected using observation. In conclusion, learning activity by applying explicit instruction model with finger painting media can increase children art skill on Kindergarten. Learning is vital to be able to create a pleasant learning environment and can give freedom to children to be able to express themselves.
\end{abstract} art

Keywords —explicit instruction; finger painting; draw; ability of

\section{INTRODUCTION}

Early childhood is a child who is at the age of zero to six years, where they are in a period of very rapid growth and development that requires stimulation and appropriate education to prepare them to face a more complex next life. Ref [1] defines that Early Childhood Education (PAUD) is a coaching effort aimed at children from birth to the age of six, which is done through providing educational stimuli to help growth and development, both physically and spiritually so that children have readiness in entering further education [2].

Early childhood is in a period of rapid growth and development so that it requires stimulus and appropriate support to optimize their growth and development. Ref [3] mentions that early childhood is in the golden age or golden age. This is because they are experiencing very rapid growth and development and will not be repeated in the future. During this golden age, early childhood has extraordinary learning desires. The right stimulus from parents, teachers and the environment around children must be given to developing abilities, creativity, and giftedness in children

At this time also maturation of physical and psychological functions occur and make children ready to respond and achieve all the developmental tasks according to the expected that it manifests through the pattern of everyday behavior. This is in line with the opinion of reference [4] who said that early childhood is a child who is in the golden age which is very potential for us to be able to train and develop various potential intelligence that they have. When this is everything in the child is very valuable, both physically, emotionally and intellectually.

Ref [4] states that develop the potential of children should be done as early as possible. The development of this potential must also pay attention to culture, social conditions, beliefs and beliefs, religion, and values that apply to the community where the child is located.

Every development shown by early childhood must receive serious attention, both from family and school to provide stimulation or stimulation that is by the stages of child development. The learning process as a form of treatment given to children must pay attention to the characteristics possessed at each stage of child development [5]. One aspect of development developed in kindergarten is the development of art. Ref [6] states that art needs to be developed since early childhood because it can develop some potential that exists in children. The development of this art is useful for the ability to think and behave in expressing their feelings.

Ref [7] reveals that art learning in kindergarten contains the content of skills, knowledge, and concepts of music, art, dance, and theatre. So, in early childhood, the development of art emphasizes more on how children carry out activities with their fine motoric skills and produce various creative activities. Based on the early childhood curriculum, it was stated that children aged 5-6 years were able to draw objects around them and were even able to express their ideas in drawing art activities.

However, the fact is in group B children in one of the kindergartens in the Barito Kuala area, in the first semester there were still many children who had not developed in the aspect of the development of art, that is at the achievement of drawing objects around it. Of the 14 children, only 2 children got four stars $(\star \star \star \star$ ) or $14,29 \%$ Excellent Development (BSB) 4 children who got three stars $(\star \star \star)$ ) or $28,57 \%$ Develop according to expectations (BSH), and 3 children who got two stars $\star \star$ ) or $21,43 \%$ Start Growing (MB), and 5 children get one star $(\star)$ or $35,71 \%$ Not Developing (BB). So, from $100 \%$ children, only $42,86 \%$ children who begin to develop and 57,14\% children are still not able to develop.

This is reinforced by the condition of children who often feel bored in participating in learning, lack of confidence in children, and children rarely even almost never draw activities 
that make them feel enthusiastic in doing so. If left unchecked it will have an impact on the development of the next child, especially for the development of children's art regarding drawing objects around them, such as children becoming less courageous in expressing their imagination and children becoming less enthusiastic or interested in participating in learning. So, it can be said that the learning atmosphere can influence children's interest in learning. This is in line with what was formulated in reference [8] that, education is a conscious and planned effort to create a learning atmosphere and learning process so that students can actively develop their potential to have religious, spiritual strength, self-control, intelligence, personality, noble character, and skills needed in society, nation, and state.

Based on the above illustration, researchers are interested in being able to overcome existing problems by applying learning to use explicit instruction model with the help of finger painting media. The use of this learning model is to make children better able to understand the learning material that teachers convey and make children more interested in learning, and children can be motivated in carrying out demonstrated activities. This is in line with the opinion of reference [9], that early childhood has a great curiosity by that children pay much attention, discuss and question various things they might have seen or heard before. Thus, the use of explicit instruction model can make children have motivation and interest in following learning because children can manipulate, imitate and create various images or works from what has been demonstrated before so that it can also foster confidence in children in producing a work based on their imagination and desires.

The cause of the delay in the development of children in kindergarten is also due to the lack of enthusiasm of children in participating in drawing learning. For this reason, researchers apply finger painting media to provide a new experience for children regarding drawing as well as to make children more enthusiastic in participating in learning activities, especially drawing activities. Reference [10] argues that finger painting is an activity of painting using fingers, expanding fine motoric skills, training the development of imagination and sharpening artistic talents, especially art activities.

Ref [10] mentions that finger painting is an experience that can attract children and impress them. Ref [10] also states that finger painting activities can help children explore the making of prizes on paper without the need to do an exercise first.

So, using this media can make children more interested in learning and able to hone their artistic abilities and imagination, and children gain experience in learning through play. The use of the learning model and media is also due in accordance with the principles that exist in the learning of Early Childhood Education (PAUD), namely: 1) children as active learners, 2) children learn through sensory and sensory, 3) children build their knowledge, 4) children think through concrete objects, 5) children learn from the environment [5].

\section{METHOD}

This study uses Classroom Action Research (CAR), consisting of stages of planning, implementation, observation, and reflection. Where before carrying out this research, the researcher first prepares the necessary materials for later learning, such as preparing learning media, tools, and materials to support the implementation of demonstrations, observation sheets, and preparation of Daily Learning Implementation Plans (RPPH).

After that, researchers can carry out the planned research. During each meeting, an observation activity was carried out to determine the extent of understanding of the child regarding the theme/material that had been delivered on that day, and after learning the progress, stages of reflection were carried out to improve deficiencies and minimize the obstacles that occurred at the first meeting.

This research was conducted in one kindergarten in the Barito Kuala area for one month, starting from March to May 2018. The research began with making proposals, arranging research permits, conducting research into the field and compiling research results. The study was conducted on children in group $\mathrm{B}$, which amounted to 14 children, with nine boys and five girls. The assessment in this study was collected through observation activities from the observation sheet of the results of the development of the child, namely behavioural aspects which included image skills and the accuracy of the image. Creativity includes dria, color, lines, shapes, lines, and clarity. Next are the main aspects of the problem, which include objects, themes, and events in the picture, ideas of events or events, themes or topics of images, expressions and emotions. The data obtained in this study were analyzed using qualitative descriptive techniques.

The criteria for the development of art in this study if, at least the results of the development of art in children reach a three-star symbol ( $\star \star \star$ ) individually and $\geq 82 \%$ of children get the Development of Expectation (BSH) or Excellent Development (BSB) category.

\section{RESUlTS AND DisCUSSION}

The results of the research conducted, it is known that at the first meeting, there were two children with the category of Not Developing (BB), in the second and third meetings there were no more children in this category. Children who get this category are due to the low aspects of children's behavior in drawing or events they say and their beliefs are still not shown optimally in terms of realizing a work. In the Beginning Developing category (MB) four children obtained it at the first meeting, at the second meeting there were two children, and at the third meeting, there were no more children in this $\mathrm{MB}$ category. Children get this category because aspect of children's behavior have begun to be able to spontaneously bring up their ideas, and begin to be able to associate images with stories or experienced with what is drawn and expressed. In the Hope Development (BSH) category there are six children who hold this meeting because they still have the strength they need, but there are still some that still need to be optimized for drawing and determining topics in the picture. Very Good Developing a category (BSB) there are two children who have their first meeting, four children at the Second meeting and six children at the third meeting because 
they can achieve a score of 90-100 with an average and almost all aspect reach the maximum.

The results of the research in the first, second and third meetings can be represented in the graph below.

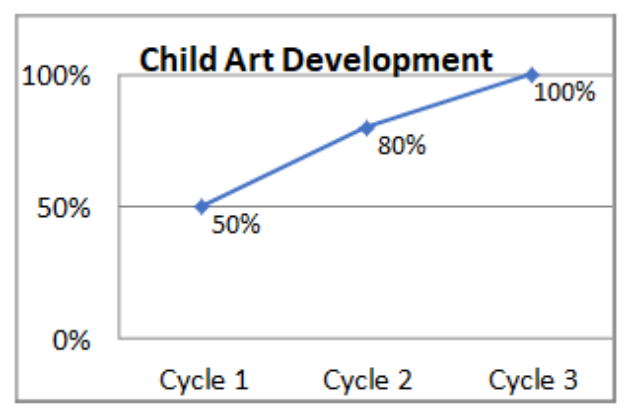

Fig. 1. Graph of Comparison of Results of Achievement of Art Development Cycle 1, 2 and 3

From the results obtained in this study, it is known that in the first cycle the results of children's art development achieved a percentage of $50 \%$ of children who succeeded in developing, in the second cycle the results of art development in children developed to $80 \%$ and reached $100 \%$ in the third cycle.

One of the success factors of this development is that during the implementation of learning the teacher has done a lot of guidance and motivation in children. This is in line with the opinion of reference [5] that, assistance to children can be given when the child is moving or when working on tasks, such ac motivating or gaining interest in the child associated with the assignment, simplifying the task so that the child is more easily managing assignment, and provide direction with the aim of helping children to be able to focus on achieving their goals.

Ref [2] states that one of the teacher's tasks is to motivate their students to be able to carry out their duties as well as possible effectively and productively. Drawing activities can also train self-confidence in children, whether they are confident to make works that are different from others or not. Ref [11] states that children need stimulation and guidelines from adults to be able to increase self-confidence, strengthen skills in learning, help develop relationships with peers, involve themselves in setting goals and evaluating, providing supervision.

Ref [11] states that to arouse learning motivation in children it is necessary to pay attention to the following things, namely topics presented interesting and useful, learning objectives and learning outcomes delivered to children, giving award in the form of praise and gifts, paying attention to differences and conditions child. $\mathrm{n}$ its implementation, the teacher has been able to run according to the opinions stated above, to be able to develop the child's abilities optimally. Giving rewards to children can make children feel excited in participating in learning; in this study, the teacher gives rewards in the form of praise to children.

Another opinion is from Ref [12] stating that the improvement of the quality of learning must be able to do the teacher, such as by generating motivation in following learning for students so that learning objectives can be achieved optimally, have high curiosity about what and how students learn and adapt to the conditions of learning in their environment.

Based on the explanation above, it is known that the development that occurs in children is caused by the teacher being able to set a learning design that is suitable with the goals to be achieved, and the teacher can provide guidance and direction that can help children during the learning process.

The development of students in each cycle is also due to applied learning innovations, where the use of explicit instruction models as well as finger painting media support in the implementation of learning, can provide stimulation that makes children more able to be actively involved during learning. This is in line with the opinion of reference [12] that, the quality of learning activities in kindergartens can be influenced by several factors, namely internal factors, and external factors which among them are in the form of social environments, such as teach communities able to give attention to improving the quality of learning in children. With different learning patterns, it can increase the enthusiasm and interest of children in learning.

The application of the explicit instruction model can make children more easily understand learning, namely with the teacher demonstrating knowledge step by step and making learning active and can make children interested in learning. Active learning is learning that emphasizes the active participation of students [12]. Students can be more active in learning materials, and the information they receive can be remembered and stored longer.

The media used also have a positive impact on students' interest in learning. The use of finger painting media can provide new experiences to students in making a work with paint media that is smeared with their fingers and can make children more enthusiastic in learning; with this media, students can also experience learning through non-boring play activities. Ref [13] argues that the method of playing by applying finger painting media can optimize children's development.

With finger painting activities can also train children to use their senses, namely the sense of touch because finger painting activities require children to be in direct contact with coloring paint using their fingers. Children's activities with direct contact with this paint can train children to be able to use their senses. This activity can also help children to recognize colors and mixing colors because in this activity children can freely choose and mix color paint that will be used for their drawing activities [4]. So, with the help of this learning media besides being able to make children more enthusiastic in learning, it can also optimize children's development.

Learning in early childhood prioritizes learning through play so that the teacher must be able to create learning that contains elements of play in it, as well as research conducted by this researcher using learning that is packaged in play activities to make children more interested in participating in art learning activities especially drawing. 
Childhood is a period of play, which is why education in kindergarten is given through playing while learning and learning while playing. We can find a learning activity program for children in kindergarten that is one keyword which is also wholeness in that goal, namely the word creativity or in other terms creativity [10]. Learning activities while playing or playing while learning will be able to develop creativity or creativity in children.

Ref [14] argues, children learn through games to be able to understand themselves. Playing is an essential thing for children, as in the education of faith and devotion and role playing. Children are active, learn to socialize and practice habits in religious life through activities such as beams, art, natural materials, role playing, and preparation. Children play with materials that they use to study various colors, numbers, and letters. They use their creativity so that they can enjoy the results of their work. This can develop their ability to be able to solve everything they are asked to do.

This study also emphasizes the freedom of children to express their ability to imagine creating a work. This is in line with reference [11] that emphasizes that children under the age of 10 are in a period called the golden age in expression ability (the golden age of creative expression). Artistic expression is one of the needs of children; therefore the freedom to work with various media and methods in children's art activities is the main approach in early childhood art education. The development of art in children also occurs because learning is presented by the stages of child development that should be. As the opinion of reference [7] also mentions that art learning in kindergarten contains the contents of knowledge, skills, and concepts from the following four fields: music, art, dance, and theatre. The role of educators here is to combine art in all activities that can be done by all children and according to their age and stages of development. Children love activities related to art because in art activities children can freely explore their talents, abilities, and skills without any coercion and binding conditions. With art activities, children's interests and talents can also be identified that have not been exposed before.

Art education contributes significantly to the formation of a whole human being; it is necessary to form a more mature goal of art education. With the existence of an art education curriculum, it is deemed necessary to know the extent of the possibility of optimizing its application for early childhood because early childhood is a golden period of development. Educational stimulation is needed to provide stimulation to all aspects of a child's development. So, art education for early childhood is essential to optimize the development of other aspects, because all aspects of development in children have integration in learning or the development of art applied in kindergarten.

One of the activities or learning of art is drawing, in this study, the drawing ability of children experiences development because children do not feel confined or experience coercion during learning. As long as learning takes place, children are invited to a pleasant atmosphere, and they are given the freedom to be able to express their imagination in an image or work without being restricted or restricted. Every child needs to be given the widest opportunity to develop without pressure from any party according to reference [14] arguing that the main task of an educator is not to suppress the feelings of children and how to channel them in a positive direction.

This is in line with reference [7] which states that drawing is an activity that is not static carried out through activities of playing textures, colors, patterns and image objects. Through images, the desire of children to express their imagination can be done directly at that moment, and there is no element of compulsion but freedom of expression.

With learning that frees children to be able to express their imagination in a work or image, it can hone creativity in children, where children are accustomed to creating an action according to their ideas so that children can actualize themselves optimally. This is in line with the opinion of Roger and Maslow in reference [10] which suggests that creativity is one aspect of personality related to self-actualization.

Ref [10] also argues that creativity is defined as the ability to be able to make new combinations based on data, information, and elements that exist. Creativity can also be interpreted as an ability that can reflect fluency, flexibility, and originality of someone in thinking.

So, in learning it is essential to be able to create a pleasant learning environment and can give freedom to children to be able to express themselves. Thus it will create a learning environment that is child-friendly and can develop the potential found in children.

Learning that is more child-centered will make learning more meaningful. What is meant by child-centered learning principles is, involving children, pleasant atmosphere, learning not in a stressful, formal or tense atmosphere, facilitating all to be able to learn [14]? So, child-based learning is learning that is applied in schools based on children's needs, oriented towards child development, learning is packaged in playing activities while learning, child-centered teaching, implementing PAKEM (Active, creative, effective and fun learning).

\section{CONCLUSIONS}

Based on the results of classroom action research carried out, it can be concluded that learning uses the explicit instruction model with finger painting media can develop children's art development in children in kindergarten.

From this study also, given suggestions to the teacher should the model and media in this study can be used as a choice in learning activities in school. It is suggested for the heads of kindergartens to improve the performance of educators in their schools for example by holding training or workshops. While for other researchers it can be used as reference material for the next research.

\section{REFERENCES}

[1] Republic of Indonesia Law Number 20 of 2003 concerning National Education System.

[2] Y. Prastika and W. Dani, "Mengembangkan Aspek Motoricik Kasar Anak Melalui Model Explicit Instuction Divariasikan dengan Permainann Tradisional," J. Pendidik. Prasekolah, vol. 1, no. 1, pp. 1-6, 2017. 
[3] R. Afriani, "Pengaruh Bermain Finger Painting Terhadap Kreativitas Anak Usia 5-6 Tahun di Raudhatul Athfal (RA) Akhlakul Karimah Kotabumi Tahun Pelajaran 2015/2016,” pp. 1-59, 2016.

[4] A. P. C. Rini, “Analisis Keterampilan Motoricik Halus Melalui Kegiatan Finger Painting pada Anak TK Kelompok Segugus PAUD 06 Imogiri Kecamatan Imogiri Kabupaten Bantul," pp. 1-120, 2013.

[5] Sujiono and N. Yuliani, Konsep Dasar Pendidikan Anak Usia Dini. Jakarta: Indeks, 2009.

[6] Zuliatin, M. Farid, and W. Denog, "2013. Pengaruh Seni Finger Painitng Terhadap Pengetahuan Warna,” J. Penelit. Psikol., vol. 4, no. 2, pp. 181-192, 2013.

[7] W. Tresnaningsih, "Kemampuan Menggambar Bebas Sebelum Pembelajaran pada Anak TK Kelompok A dan B TK Al'Idad An-Nuur," J. Pendidik. Guru Pendidik. Anak Usia Dini, vol. 7, no. 4, pp. 1-11, 2015.

[8] Munawar and Mujiono, "Hakikat Manusia, Hakikat Pendidikan dan Tujuan Pendidikan,” Makal. Pascasarjasa Univ. Negeri Semarang, 2012.

[9] M. A. Aulia, "Upaya Mengembangkan Aspek Motoricik Halus dalam Mengkoordinasikan Mata dan Tangan untuk Melakukan Gerakan yang
Rumit Menggunakan Kombinasi Model Explicit Instruction dan Metode Pemberian Tugas pada Anak Kelompok ATK Bu,” 2013.

[10] D. S. Kurnia, "Pengaruh Kegiatan Painting dan Keterampilan Motoricik Halus Terhadap Kreativitas Anak Usia Dini dalam Seni Lukis," J. Pendidik. Anak Usia Dini., vol. 9, no. 2, pp. 285-302, 2015.

[11] A. Loita, "Karakteristik Pola Gambar Anak Usia Dini,” J. Pendidik., vol. 1, no. 1, pp. 1-14, 2017.

[12] D. Wahyudi and Y. Prastika, "Upaya Mengembangkan Aspek Motoricik Kasar Anak TK Kelompok B Menggunakan Model Explicit Instruction Divariasikan dengan Permainan Tradisional,” J. Paradig., vol. 10, no. 2, pp. 29-33, 2015.

[13] N. Astria, M. Sulastri, and M. Magta, "Penerapan Metode Bermain Melalui Kegiatan Finger Painting untuk Meningkatkan Kemampuan Motoricik Halus," e-Journal PG-PAUD, vol. 3, no. 1, 2015.

[14] N. Khotimah, "Pembelajaran Berbasis Anak dalam Pengembangan Bidang Seni (Rupa) di PAUD Batik dan PAUD Sabitul Azmi Sidoarjo. Harmonia," vol. 12, no. 2, pp. 143-150, 2012. 